\title{
Utjecaj transformacije inovacijskog sustava na promjenu kvalitete tehnoloških sektora CEE zemalja
}

\section{The impact of the transformation of the innovation system on the change in the quality of the technology sectors of CEE countries}

\section{Sažetak}

Zemlje centralne i istočne Europe (CEE) u posljednjih 30 godina prošle su kroz dvije značajne političke, odnosno institucionalne transformacije, koje su izazvale snažne efekte na gospodarskom inovacijskom planu zemalja. Međutim, transformacijom sustav nije u potpunosti iščeznulo političko, institucionalno i tehnološko nasljeđe planske ekonomije. Ovim radom analizirati će se utjecaj transformacije inovacijskog sustava na promjenu kvalitete tehnoloških sektora CEE zemalja. Naime, promatrati će se promjene kvalitete inovacija pojedinih tehnoloških sektora tijekom tri vremenska razdoblja kroz koje su CEE zemlje prošle. Priljevom stranog kapitala, ali i tehnologije i znanja, CEE zemlje bilježe pozitivne pomake u kvaliteti njihovih inovacija, međutim, vrijeme provedeno u planskoj ekonomiji rezultiralo gradnjom specifičnih proizvodnih kapaciteta, te prelaskom na tř̌išno gospodarstvo navedene zemlje nisu se uspjele značajno osloboditi tehnološkog nasljeđa. Naime, razumijevanje dugoročnih trendova kretanja tehnološkog portfelja zemlje pomoći će u orijentaciji javne politike, investicija, smanjenje rizika ulaganja što će rezultirati rastom efikasnosti u inovacijskog sustava.

Ključne riječi: planska ekonomija, CEE, EU, inovacije, tehnološki portfelj

JEL klasifikacija: 025, 033, P41,P51

\section{Abstract}

The countries of Central and Eastern Europe (CEE), in the last 30 years, have undergone two significant political and institutional transformations, which have caused strong effects on the country's economic and innovation agenda. However, the transformation of the system did not completely eliminate the political, institutional and technological heritage of the planned economy. This paper will analyze the impact of the innovation system transformation on quality of CEE countries technology sectors. Namely, changes in the quality of innovation of each individual technology sectors will be observed during the three time periods that CEE countries have undergone. With the inflow of foreign capital, technology and knowledge, CEE countries record positive changes in the growth of innovation quality. However, time spent in the planned economy left significant trace in building specific capacities, that way disabled changes in technology portfolio. Understanding the long-term trends in the country's innovation quality, and technology portfolio, will help set public policy, which will result in increased efficiency in the innovation system.

Keywords: planned economy, CEE, EU, innovation, technological portfolio

JEL classification: 025, 033, P41, P51

\section{Davor Vlajčić}

Doc.dr.sc.

Ekonomski fakultet Sveučilišta u Zagrebu E-mail:dvlajcic@net.efzg.hr

\section{Mile Bošnjak}

Doc.dr.sc.

Ekonomski fakultet Sveučilišta u Zagrebu

E-mail: mbosnjak1@net.efzg.hr

\section{Davor Vlajčić}

Asst. prof.

Faculty of Economics and Business, University of Zagreb

E-mail:dvlajcic@net.efzg.hr

\section{Mile Bošnjak}

Asst. prof.

Faculty of Economics and Business, University of Zagreb

E-mail: mbosnjak1@net.efzg.hr 
Vlajčić, D., Bošnjak, M.

Utjecaj transformacije inovacijskog sustava na promjenu kvalitete tehnoloških sektora CEE zemalja

\section{Uvod}

Sile kreativnog uništenja su glavni uzročnik promjena u tržišnoj strukturi (Schumpeter, 1934.). Naime, one su odgovorne za napuštanja postojećih starih tehnologija koje su korištene u proizvodima, procesima i praksama, te njihovu zamjena boljim i kvalitetnijim tehnološkim modelima. Klepper (1996.) je navedeni fenomen povezao s tehnološkim ciklusima u kojima je dominantna tehnologija istisnuta novom tehnologijom. Navedeni autor smatra kako zamijenjena tehnologija predstavlja temelj na kojem kreće novi ciklus. Kako bi se uspješno nosili sa tehnološkim promjenama, nužno je kvalitetno upravljanje trenutnom inovacijskom infrastrukturom, ali i tehnološkim nasljeđem. Tehnološko nasljeđe rezultat je dugogodišnjih inovacijskih politika, što je prema Radosevicu (1999.), zaslužno je za tehnološki portfelj zemalja. Zemlje istočne Europe (CEE), su u posljednja tri desetljeća prošle kroz dvije značajne političke transformacije, koje su ostavile traga i na njihovim gospodarskim sustavima. Naime, napuštanje modela disciplinirane, planske ekonomije i prihvaćanje obilježja tržišne ekonomije (Kirankabeş i Erkul, 2019.), te pridruživanje navedenih zemalja zajednici europskih „razvijenih“ zemalja (EU) potaknulo je značajne institucionalne promjene (Carmin i VanDeveer, 2004.). Otvaranje ekonomije, omogućilo je zemljama dostupnost globalnih resursa i sredstava. Naime, prelaskom s planskog na tržišno gospodarstvo, te ulaskom u EU, CEE zemlje bilježe priljev inozemnih tehnologija, državne kompanije postale su izložene stranoj konkurenciji, te je izgubljen povlašteni tretman koji su navedene kompanije njegovale u planskoj ekonomiji, a koji ih je učinio tehnološki inferiornijima (Guillén, 2000.) Promjena političkog i institucionalnoga okvira rezultiralo je disrupcijom, odnosno reorganizacijom inovacijskog sustava. Usklađenost $s$ tehnološkim ciklusima odnosno suvremenim trendovima u razvoju tehnologija osigurava mjesto na svjetskom tržištu. Međutim, podizanje kvalitete inovacija čini zemlju konkurentnijom (Boutellier i suradnici, 2013.). Ovim radom analizirati će se utjecaj transformacije inovacijskog sustava na promjenu kvalitete tehnoloških sektora CEE zemalja. Naime, promatrati ce se promjene kvalitete inovacija tehnoloških sektora tijekom tri vremenska razdoblja kroz koje su CEE zemlje prošle. Analiza će pratiti tri razdoblja koja su ostavila najznačajniji trag na razvoj suvremene povijesti 11 zemalja CEE regije. Vrijeme planske ekonomije, napuštanje planske ekonomije i prihvaćanje obilježja tržišne ekonomije, te vrijeme provedeno u zajednici „razvijenih“ zemalja (ulazak navedenih zemalja u Europsku uniju). Koristeći deskriptivnu statistiku, analizirati će se međunarodno prepoznatih patenata prema tehnološkoj klasifikaciji, na taj način omogućiti će se usporedba pomaka u kvaliteti inovacija pojedinih tehnoloških sektora. Naime, razumijevanje dugoročnih trendova kretanja tehnološkog portfelja zemlje pomoći će u orijentaciji javne politike, investicija, smanjenje rizika ulaganja što će rezultirati rastom efikasnosti u inovacijskog sustava.

U nastavku rada slijedi pregled literature 0 institucionalnim transformacijama CEE zemalja. Nakon toga slijedi opis korištene metodologije, te analiza podataka. Zatim će se provesti diskusija 0 promatranim podacima, a na koncu će uslijediti zaključak.

\section{Pregled literature}

Zemlje centralne $i$ istočne Europe (CEE) u posljednjih 30 godina prošle su kroz dvije značajne političke, odnosno institucionalne transformacije. Naime, navedene zemlje, početkom 90 -ih godina prošlog stoljeća napustile su sustav planske ekonomije i prihvatili karakteristike tržišne ekonomije (Kirankabeş i Erkul, 2019.), a početkom 2000-ih postale punopravne članice Europske unije (detalje možete pronaći na službenoj stranici Europske Unije). Valja napomenuti kako su promjene sustava bile znatno radikalnije prelaskom na sustav tržišnog gospodarstva nego prilikom pristupanja EU. Prelazak na tržišno gospodarstvo rezultirao je reorganizacijom uloga pojedinih aktera, što je dovelo do disrupcije inovacijskog sustava (Radosevic, 1999.). Implementacija poslovnog sektora u inovacijske aktivnosti predstavlja značajni pomak od institucionalno koordiniranog sustava. U usporedbi s drugim planskim ekonomijama, poput Kine koja je koristila evolucijski pristup transformacije sustava, tranzicija CEE zemalja bila je znatno šokantnija, obzirom kako se inzistiralo na brzom i naglom prelasku 
na tržišno gospodarstvo (McMillan i Naughton, 1992.), generiravši tako dodatne pritiske na nove sudionike inovacijskog procesa. Sustav planske ekonomije koji je aktivnosti istraživanja i razvoja u potpunosti odvojio od poslovnog sektora, bio je pretežito fokusiran na znanost $i$ istraživanje, što je rezultiralo padom interesa za razvoj inovativnih rješenja i tehnologije (Radosevic, 1999.), a time i padom konkurentnosti CEE zemalja. Osim političke izoliranosti, ne konkurentnost je dodatno smanjila suradnju s inozemstvom, te time oslabile mogućnosti apsorpcije inozemne tehnologije. Otvaranjem gospodarstva tržište CEE zemalja bilježi priljev inozemnih tehnologija i ulazak privatnih kompanija na tržište istraživanja i razvoja (Bradshaw, 2017.). Državne kompanije postale su izložene stranoj konkurenciji, te je izgubljen povlašteni tretman koji su navedene kompanije njegovale u planskoj ekonomiji (Guillén, 2000.). Ulazak poslovnog sektora doveo je do ulaska sviježeg privatnog i inozemnog kapitala, koji je zamijenio prijašnje institucionalno financiranja (Radosevic i Auriol, 1999.). Navedeno je otvorilo brojna pitanja glede uloge državnog financiranja u sektoru istraživanja i razvoja. Kozlowski i suradnici (1999.) u svom radu navode kako nužno da država zadrži prioritetni položaj u financiranju obrazovnog sektora i primarnih istraživanja. Također, u istom istraživanju autori ukazuju kako država nije i ne smije u potpunosti odstupila od financijskog podupiranja i ostalih ne-državnih aktera koji sudjeluju u inovacijskom sustavu. Nasuprot značajnih promjena u političkoj i ekonomskoj strukturi napuštanjem planske ekonomije, ulazak u Europsku unije sa sobom nije povukao toliko značajne strukturne promjene. Proces ulaska zahtijevao je postupne prilagodbe institucionalnog regulatornog okvira (Börzel i Sedelmeier, 2017.). Srž djelovanja Europske unije je,kroz brojne regulatorne transformacije, uklanjanje tržišne nesavršenosti, optimizacija proizvodnje i konvergencija ka ostalim zemljama članicama. Međutim, valja napomenuti kako i sam regulatorni okvir Europske unije prolazi kroz brojne transformacije prilagođavajući se trendovima OECD zemalja (Pelkmans i Renda, 2014.). CEE zemlje pristupile su Europskoj uniji (počevši od 2004. godine) u trenutku kada su ciljevi Unije bili usmjereni ka regulaciji četvrte generacije financijskih usluga, zaštite okoliša i intervencijama u energetskom sektoru (EXPRESS, 2010). Važne promjene $u$ inovacijskim sustavima CEE zemlje doživjele su omogućavanjem pristupa europskim fondovima kojima se promovira napredak tehnoloških istraživanja. Od 1984. godine pa sve do danas Europska unija kreirala je devet programa financiranja (FP1- FP9), a CEE zemlje priključile su se EU u trenutku djelovanja „FP6“ i „FP7“. nakon kojega je uslijedio "Horizon 2020" (završio 2020.) a od 2021. pokrenut je "Horizon Europe" (European Commission, 2020.). Tranzicijom (EE zemalja na tržišno gospodarstvo, navedene zemlje nisu se preko noći mogle riješiti svog institucionalnog nasljeđa, a Karo i Kattel (2015.) ukazuju kako je upravo uspješna prilagodba naslijeđenog inovacijskog okvira CEE zemalja ključna kako bi se osigurao stabilan rast gospodarstva. U vrijeme kada se planski koordiniralo ekonomske aktivnosti, tehnološki portfelji CEE zemlje bio je koncentriran pretežito oko „Kemijske industrije“ (eng. Chemical industries) i „Strojarske industrije“ (eng. Mechanical engineering), kako navedena polja klasificira Svjetska organizacija za intelektualno vlasništvo (Dominguez i Giebler, 2014.; Lacasa i suradnici, 2017.). Novoformirana autonomija inovacijskog sustava i pojačana konkurentnost na tržištu nisu rezultirali promjenom dominantnih istraživačkih polja. Navedeno je prvenstveno vidljivo u inovacijskim aktivnosti pod državnom upravom, gdje se zadržala dominacija inovacija iz polja „Kemijske industrije“ $i$ „Strojarske industrije“.Naime, unatoč tranziciji iz planskog u tržišno gospodarstvo, CEE zemlje baziraju svoje istraživačke aktivnosti na poljima u kojima je postupno kroz godine kumulirala znanje, te se na koncu i specijalizirala u navedenom (Boschma i suradnici, 2015.), vjerujući kako je jedino na taj način moguće postići sinergiju između svojih tehnoloških aktivnosti. To je nakratko dovelo do pitanja kompatibilnosti između državno koordiniranih istraživačkih institucija i istraživačkih aktivnosti privatnog kapitala koji je došao iz inozemstva. Međutim, detaljna analiza patenata privatnog sektora ukazuje na sličnu strukturu kao što pokazuju i istraživačke institucije pod državnom upravom.

Poznato je kako je većina inovatora svakodnevno u dilemi uslijed rizika kako neće opravdati trošak inoviranja. Brojna istraživanja ukazuju na problem velikog broja beskorisnih inovacija, a nalazi
Vlajčić, D., Bošnjak, M.

Utjecaj transformacije inovacijskog sustava na promjenu kvalitete tehnoloških sektora CEE zemalja 
Vlajčić, D., Bošnjak, M.

Utjecaj transformacije inovacijskog sustava na promjenu kvalitete tehnoloških sektora CEE zemalja pojedinih autora uvelike se razlikuju. Naime, prema istraživanju Giuri i suradnici (2007.) svega $17 \%$ svih inovativnih rješenja nije bilo nikada korišteno, s druge strane Sichelman (2010.) ukazuje na beskorisnost $50 \%$ inovacija, dok istraživanje Stephen Key ukazuje kako 90\% svih razvijenih tehnologija nikada neće opravdati trošak ulaganja. Prema PATVAL anketi (Giuri i suradnici, 2007.), gotovo $40 \%$ svih patenata (razvijenih tehnologija) se ne koristi u komercijalne svrhe, već kako bi blokirali druge konkurente od korištenja njima potrebne tehnologije. Modularnost i kompleksnost suvremenih proizvoda zahtijevaju znatno veći angažman inovatora, odnosno radikalan pristup inovacijskom procesu. Promjene u arhitekturi proizvoda zahtijevaju re-kombinaciju odnosno re-konfiguraciju postojećeg znanja kako bi uspješno inovirale (Hacklin i suradnici, 2013.; Kodama, 2009.). Kako bi se generirale radikalne, kvalitetnije, inovacije nužna je i radikalna promjena tehnološkog portfelja. Diversifikacija tehnološkog portfelja omogućava generiranje radikalnih inovacija (Chen i suradnici, 2013.). Diversifikacija je kompleksan proces sa sobom nosi i neke nepopularne posljedice, kao što su povećani troškovi koordinacije i komunikacije unutar tehnološkog portfelja. Međutim, to je mala cijena kako bi se izbjegla nemogućnost brze adaptacije na suvremene inovacijske trendove. Naime, tehnološki ciklusi kontinuirano mijenjaju tehnološke putanje pojedinih zemalja, a samim time i njihovu konkurentnost (Schumpeter, 1934.). Brojna istraživanja o tehnološkim ciklusima kontinuirano proučavaju kako potražnja na tržištu oblikuje tehnološke trendove, odnosno kako definira dominantan dizajn (Murmann i Frenken, 2006.). Smatra se kako su navedeni ciklusi vrlo često snažno ovisni o prijašnjim, naslijeđenim tehnološkim putanjama, međutim, također pretpostavljaju kako prijašnja dominantna tehnologija mora u jednom trenutku dosegnuti svoj limit i iščeznuti (Fleming, 2001.; Dosi, 1982.; Adner i Snow, 2010.). Kao što je već gore navedeno, prelaskom s planskog na tržišno gospodarstvo, CEE zemlje bilježe priljev inozemnih tehnologija i privatnih, dok je ulaskom u EU, navedenim zemljama dostupni su razni modeli poticaja i pomoć kako bi se što prije postigla konvergencija s ostalim zemljama EU. Međutim, postavlja se jasno pitanje da li su navedene tranzicije zaista ostavile traga u građenju konkurentnosti CEE zemalja.Konkurentnost zemalja uvelike ovisi o kvaliteti inovacija, koja se evidentira kroz međunarodnu prepoznatljivost inovacija, ali i praćenjem suvremenih trendova i smjerova razvoja tehnologija. Dakle, broj inovacija nije nužno vjerodostojan pokazatelj uspješnosti inovacijskog okvira neke zemlje, već napore treba usmjeriti ka mjerenju kvalitete tih inovacija. Ovim radom kroz deskriptivnu statistiku, analizirati će se pomaci u kvaliteti inovacija kroz 3 razdoblja u zemljama CEE regije, te kako su ti pomaci promijenili tehnološke smjerove u navedenim zemljama.

\section{Metode i istraživanje}

Kvaliteta inovacija složen je konstrukt, te mjerljivost navedenog konstrukta nije lako postići. U svojem istraživanju Harhoff i suradnici (2003.) je pokušao mjeriti kvalitetu koristeći anketni upitnik kojim je inovatore ispitivao o monetarnoj vrijednosti njihove inovacije. U njihovu istraživanju naglasak je bio na cijeni za koju su inovatori voljni ustupiti patent na korištenje ili ga prodati. S druge strane, Hall i suradnici (2005.) su kroz proučavanje financijskih izvještaja kompanija pokušali izmjeriti ekonomski doprinose vrijednosti kompanije koji pružaju patenti i ostala nematerijalna imovina. Na koncu možda najčešće korištena metoda određivanja kvalitete inovacija analiza je podataka o patentnoj proceduri. Već je prije navedeno kako se inovacije u akademskoj literaturi vrlo često poistovjećuju sa patentima. Valja napomenuti kako metrika zasnovana na patentima samo „proxy“ obzirom kako oni ne sadržavaju informacije o tržišnim transakcijama niti stvarnoj uporabi tehnologije (Squicciarini i suradnici, 2013.). Analiza podataka iz patentne procedure donosi čitav niz instrumenata kojima bi se mogla ocijeniti kvaliteta inovacija. Među najvažnijima tu su odobreni patenti (eng. Granted patents), broj citata (eng. Forward citation) kojim se mjeri utjecaj na buduće tehnologije, broj inovatora (eng. Number of inovators) koji prikazuje trošak inovacije/istraživanja, obnova patenta (eng. renewals) koja mjeri trošak održavanja patenta, te opozicija (eng. oposition) koja mjeri tržišnu vrijednost/trošak pravne procedure sukoba. Kako bi se ocijenila kvaliteta inovacija ovaj rad koristiti će indikator veličine patentne obitelji (eng. family size). Naime, ovaj indikator kroz trošak zaštite u više 
jurisdikcija predstavlja znak tržišnog potencijala. Pregledom prijašnje literature (Lanjouw i Schankerman, 2004.; Guellec i van Pottelsberghe de la Potterie, 2000.; Harhoff i suradnici, 2003.; Ejermo, 2009.) potvrđuje se kako je navedeni indikator izvrsna metrika za kvalitetu inovacija. Promatrane zemalja su Mađarska, Estonija, Litva, Latvija, Republika Češka, Poljska, Slovenija, Slovačka, Bugarska, Rumunjska i Hrvatska. Navedene zemlje su od strane OECD-a (2001.) definirane kao zemlje središnje i istočne Europe (CEE). Navedeni indikator predstavlja odgovarajuću mjernu jedinicu obzirom kako su promatrane zemlje dugo prakticirale plansku ekonomiju, okarakteriziranu zatvorenim sustavom sa malom međunarodnom suradnjom i povezanošću, te su se smatrale nekonkurentnim na svjetskom inovacijskom tržištu. Stoga, svaka internacionalizacija patenata predstavlja izniman pomak u pogledu vrijednosti inovacija CEE zemalja. Istraživanje će se temeljiti na analizi patentnih prijava (eng. Patent applications). lako su odobreni patenti (eng. Granted patents) bolji indikator za inovacije, ovaj rad koristi će patentne prijave zbog dugotrajnosti postupka odobravanja patenta (u prosjeku 4 godine). Naime, indikator odobreni patenti ima ograničenu mogućnost obuhvaćanja novijih inovacija (Guellec i Van Pottelsberghe de la Potterie, 2002.). Za pristup podacima korišten je Espacenet, online alat razvijen od Europskog patentnog ureda. Kako bi se izvukli podaci koji predstavljaju patentne obitelji, za svaku zemlju izdvojene su sve patentne prijave koje, osim svoje nacionalne prijave, imaju i prijave u barem jednoj zemlji van nacionalnih granica (eng. Patent family). Kako bi se patent klasificirao kao domaći patent promatralo se samo patentne prijave čiji su izumitelj i osobe koje su prijavile zahtjev za zaštitu iz promatrane zemlje. Nadalje, podaci su filtrirani prema tri vremenska razdoblja, prvo je bilo razdoblje kada su se promatrane zemlje nalazile u planskoj ekonomiji (do 1991.), zatim razdoblje u tržišnoj ekonomije (1991. -ovisno o periodu ulaska $\mathrm{u}$ EU), te naposljetku razdoblje u tržišnoj ekonomije, ali od ulaska u EU (ovisno o periodu ulaska u EU). Kako bi se dobio detaljniji uvid u promjeni kvalitete inovacija promatrani su pomaci u pojedinim industrijskim sektorima, te je u tu svrhu korištena klasifikacija Svjetske organizacije za intelektualno vlasništvo (WIPO, 2021.), koja razlikuje 5 sektora i 35 tehnoloških polja. Korištena je deduktivno logička metoda usmjerena na postojeća istraživanja, dinamiku i usporedbu navedenih pokazatelja.

\section{Analiza}

Analizom patentnih obitelji CEE zemalja utvrđuje se kako u vrijeme planske ekonomije promatrane zemlje bilježe značajan broj svojih patenata, osim u nacionalnim okvirima, registrirane i u inozemstvu (kvaliteta inovacija), u slučaju, Slovenije, Češke, Slovačke, Hrvatske, Latvije ta brojka iznosi $100 \%$. Međutim, za Bugarsku, Rumunjsku i Poljsku ta brojka ne prelazi 3\%. Nadalje, u periodu tranzicije na tržišno gospodarstvo, broj internacionalno registriranih patenata značajno se smanjuje. Mađarska, Slovenija, Češka, Slovačka, Hrvatska i Estonija bilježe dvoznamenkaste brojeve, međutim ti iznosi ne prelaze $20 \%$, osim u slučaju Slovačke kojoj udio inozemno registriranih patenata u ukupnom broju patenata iznosi 25\%. Važno je napomenuti kako Bugarska, Rumunjska i Poljska i dalje ne bilježe značajan pomak, u odnosu na period kad su bile u planskoj ekonomiji, u udjelu inozemno registriranih patenata. Ulaskom pojedinih zemalja u Europsku uniju udio inozemno registriranih patenata u ukupnom broju patenata doživio je značajan rast u većini CEE zemalja. Međutim, važno je iz ovog uzorka izdvojiti Hrvatsku i Slovačku, koje suprotno ostalim CEE zemljama bilježe smanjenje udjela inozemno registriranih patenata u ukupnom broju patenata (detalji se mogu pronaći u Tablici 1. i Grafikonu 2.u dodatku).

Grafikon 2. pokazuje promjene u prepoznatljivosti inovacija (kvaliteta inovacija) odabranih CEE zemalja na inozemnom tržištu, zabilježene kroz promatrana razdoblja, u pojedinim industrijskim sektorima. Analiziraju se razlike u 5 sektora, ali i 35 tehnoloških polja sadržanih unutar navedenih sektora. Kroz analizu navedenih grafova jasno se vidi kako zemlje poput Poljske, Mađarska, Latvije i Slovenije prepoznatljivost na inozemnom tržištu inovacija kroz sva tri promatrana perioda najviše zahvaljuju svojoj kemijskoj industriji. Od navedenih zemalja Mađarskoj je od vremena planske ekonomije pa sve do danas preko $90 \%$ svih inozemno registriranih patenata bilježila u sektoru kemijske industrije, prvenstveno se to odnosi na tehnološka polja farmaceutike i organske
Vlajčić, D., Bošnjak, M.

Utjecaj transformacije inovacijskog sustava na promjenu kvalitete tehnoloških sektora CEE zemalja 
Vlajčić, D., Bošnjak, M.

Utjecaj transformacije inovacijskog sustava na promjenu kvalitete tehnoloških sektora CEE zemalja

Tablica 1. Udio inozemno registriranih patenata u ukupnom broju patenata

\begin{tabular}{|c|c|c|c|}
\hline & Planska ekonomija (\%) & $\begin{array}{c}\text { Tržı̌na ekonomija } \\
\text { (prije ulaska u EU) (\%) }\end{array}$ & $\begin{array}{c}\text { Tržišna ekonomija } \\
\text { (poslije ulaska u EU) (\%) }\end{array}$ \\
\hline Mađarska & 32,57 & 10,05 & 20,76 \\
\hline Poljska & 1,21 & 1,17 & 7,30 \\
\hline Slovenija & 100,00 & 17,06 & 33,46 \\
\hline Češka & 100,00 & 10,19 & 12,66 \\
\hline Slovačka & 100,00 & 25,98 & 11,82 \\
\hline Hrvatska & 100,00 & 16,04 & 14,08 \\
\hline Bugarska & 2,16 & 4,17 & 7,89 \\
\hline Rumunjska & 0,39 & 0,83 & 3,08 \\
\hline Estonija & $n / a$ & 10,23 & 20,19 \\
\hline Latvija & 100,00 & 7,26 & 10,88 \\
\hline Litva & $n / a$ & 2,22 & 26,18 \\
\hline
\end{tabular}

Izvor: izrada autora.

kemije. Kroz vrijeme udio polja organske kemije smanjuje se u korist polja farmacije. Slovenija bilježi slične trendove. Naime, gotovo $60 \%$ svih inozemno registriranih patenata dolazi iz sektora kemijske industrije, gdje se također može primijetiti, kako se kroz vrijeme udio polja organske kemije smanjuje u korist polja farmacije. Također, zamjetan je pad udjela elektrotehnike i strojarstva, koji je bio prvenstveno razvijen u vrijeme planske ekonomije. U slučaju Poljske, gotovo 60\% svih inozemno registriranih patenata dolazi iz sektora kemijske industrije. Naime, primjetan je značajan rast farmaceutske industrije, pa je tako u vremenu planske ekonomije on iznosio svega $6 \%$, da bi danas udio farmaceutike iznosio 30\% svih inozemno registriranih patenata. Također se može vidjeti kako je tradicionalno kroz sva promatrana razdoblja jako polje građevinarstva (oko 10\%). Za razliku od ostalih zemalja Češka prepoznatljivost na inozemnom tržištu inovacija u vrijeme planske ekonomije nije temeljila isključivo na kemijskoj industriji.U promatrano vrijeme naj prepoznatljivije inovacije dolazile su iz sektora strojarstva (gotovo $60 \%$ ), prvenstveno iz tekstilne i papirne industrije (43\%), dok je kemijska industrija pokrivala $30 \%$ inozemnih patenata. Prelaskom na tržišno gospodarstvo, a pogotovo ulaskom u EU, Češka je na inozemnom tržištu značajno promijenila svoj smjer specijalizacije, te je primarni sektor inozemne prepoznatljivosti postao sektor kemijske industrije, dok je sektor strojarstva zabilježio značajan pad. Slična priča ponavlja se i u Slovačkoj. Naime, u vrijeme planske ekonomije Slovačka je bila prepoznata na inozemnom tržištu kroz inovacije iz sektora strojarstva (gotovo 60\%), međutim prelaskom na tržišno gospodarstvo, naglasak je prebačen na sektor kemijske industrije, preko 50\%. Ulaskom u EU, Slovačka je svoju prepoznatljivost počela graditi i na sektorima strojarstva i elektrotehnike. Slično Slovačkoj, značajne pomake u inozemnoj prepoznatljivosti inovacija Bugarska bilježi u sektoru elektrotehnike. Unatoč dominaciji kemijske industrije (prvenstveno metalurgija i metali) u planskoj ekonomiji, prelaskom na tržišnu ekonomiju i ulaskom u EU, sektor elektrotehnike zabilježio je značajan porast. U Republici Hrvatskoj kemijska industrija tradicionalno je vodeća industrijska grana. Isti trend nastavlja se prelaskom na tržišno gospodarstvo, te Hrvatska u promatranom periodu bilježi gotovo $80 \%$ od svih svojih inovacija koje su prepoznate van svojih granica u kemijskoj industriji. Od ulaska u EU na značaju je dobio sektor strojarstva i građevinarstva. U vrijeme planske ekonomije Rumunjska je bila prepoznata po svojoj kemijskoj industriji, to se prvenstveno odnosilo na farmaceutiku, kemijski inženjering. Također, na tehnološku mapu svijeta, Rumunjsku je držao sektor strojarstva. Međutim, uspostavom tržišnog gospodarstva, a pogotovo ulaskom Rumunjske u EU udio kemijske industrije u inozemnim patentima uvelike se smanjuje a značajno raste udio sektora elektrotehnike, prvenstvo polje kompjuterske tehnologije. U slučaju Estonije, prepoznatljivost na svjetskoj sceni prvenstveno je rezultat industrije hrane (15\%), farmacije (8\%), medicinske tehnologije (21\%) te ostalih strojeva (9,2\%). Ulaskom u EU, medicinska tehnologija gubi značaj, dok su ostala prethodno 
navedena polja i dalje prioritetni segmenti u tehnološkom portfelju Estonije. Značajne pomake u prepoznatljivosti inovacija na inozemnom tržištu Litva je doživjela ulaskom u EU. Naime, kemijska industrije (prvenstveno farmaceutska i organska kemija) zabilježila je značajan pad udjela u inozemnim patentima. Suprotno tome, izuzetno veli porast bilježi sektor instrumenata, pogotovo optički instrumenti.Za detaljniji pregled i sektorsku analizu patenata registriranih u inozemstvu vidjeti Grafikon 1. te Tablicu 2. u dodacima.

\section{Rasprava}

Ovo istraživanje pokazuje kako je u periodu planske ekonomije vladala velika međunarodna prepoznatljivost inovacijskih aktivnosti CEE zemalja koje su u periodu prije devedesetih godina živjele u zajednicama, poput Čehoslovačke ili Jugoslavije. Ovo bi moglo navesti na zaključak kako su inovacije iz promatranih zemalja bile od visoke vrijednosti. Međutim, dublja analiza ukazuje kako su inovacije promatranih zemalja (pogotovo iz kemijske industrije i industrije metalurgije) pretežito prepoznate u drugim zemljama planskim ekonomijama, prvenstveno u zemljama s kojima su bile u zajednici (Kutlaca,1999.), dok je prepoznatost istih inovacija u zapadnim razvijenijim zemljama znatno manja. Stoga, može se pretpostaviti kako je veliki udio međunarodno prepoznatih inovacija u planskoj ekonomiji rezultat snažne ekonomske i političke suradnje s drugim planskim ekonomija. Lokalne suradnje, prema Picci (2010.) pretežito rezultiraju inkrementalnim inovacijama, dok su za radikalne inovacije odgovorne suradnje tehnološki i geografski udaljenih konzorcija (Moodysson i Jonsson, 2007.). Prethodno navedeno daje naslutiti kako su inovacije promatranih zemalja inkrementalne naravi, što je i bilo uzrok njihove globalne ne-konkurentnosti. S druge strane, rezultati pokazuju kako je međunarodna prepoznatljivost inovacijskih aktivnosti Poljske, Bugarske i Rumunjska na izuzetno niskim razinama, što se može obrazložiti činjenicom kako promatrane zemlje nisu bile dio nekakve zajednice, te su njihovi istraživačko-razvojni napori ostali izolirani. Za razliku od prethodne tri zemlje rezultati inovacijske aktivnost Mađarske znatno su prepoznatljiviji na inozemnom tržištu. Naime, prve elemente tržišnog gospodarstva Mađarska prihvatila puno prije ostalih CEE zemalja prihvaćanjem novih ekonomskih mehanizama 1968. godine (Hare, 1991.; Balázs, 1993.), te je za razliku od ostalih promatranih zemalja razvila konkurentnije gospodarstvo, ali i inovacijski sustav. Prelaskom na tržišno gospodarstvo zemlje bilježe priljev inozemnog kapitala (Kriaucioniene i Ragauskas, 2008.), koji generira prve znakove međunarodne suradnje u istraživanju i razvoju sa zapadnim zemljama. Navedeno je rezultiralo podizanjem kvalitete inovacijskih aktivnosti, a time i konkurentnosti promatranih zemalja. Uslijed toga u razdoblju od početka devedesetih pa sve do ulaska u EU počinje se zamjećivati prepoznatljivost inovacijskih aktivnosti i van CEE okvira. Od ulaska u EU do danas gotovo sve promatrane zemlje zabilježile su rast udjela međunarodno registriranih patenata u ukupnom broju patenata. Navedeno se može zahvaliti snažnom rastu suradnje s ostalim zemalja EU, te koordiniranim inovacijskim politikama i mjerama kojima je cilj konvergencija razvoja svih EU zemalja. Iznimka se pojavljuje na primjeru Republike Hrvatske i Slovačke. Slovačka u promatranom periodu ima puno brži rast ukupnih patenata, od međunarodno prepoznatih patenata (Espacenet, 2021.). Prethodno navedeno ukazuje kako razina konkurentnosti Slovačke ne raste istom brzinom kao što se to zamjećuje u ostalim zemljama CEE regije. Obzirom kako se međunarodna prepoznatost inovacija uvelike temelji na međunarodnoj suradnji, može se zaključiti kako negativni trendovi Slovačke rezultat slabije prilagodbe na uvijete europskog tržišta. Slični scenarij može se replicirati i na primjeru Hrvatske. Međutim, Hrvatska je u EU ušla znatno kasnije (2013. godine), te nije za očekivati kako će u tako kratkom roku u potpunosti iskoristiti sve istraživačke i razvojne kapacitete koje EU nudi. Tehnološki ciklusi kontinuirano mijenjaju tehnološke putanje pojedinih zemalja, a brza adaptacija na suvremene inovacijske trendove ključ za održavanje konkurentne pozicije (QuintanaGarcía i Benavides-Velasco, 2011.). Rezultati istraživanja pokazuju snažnu dominaciju industrije organske kemije i farmaceutike u Mađarskoj tijekom sva tri promatrana razdoblja. Rezultat je to stogodišnjeg kontinuiranog ulaganja u promatrano polje. Naime, začetke farmaceutske industrije u Mađarskoj možemo pronaći još prije prvog
Vlajčić, D., Bošnjak, M.

Utjecaj transformacije inovacijskog sustava na promjenu kvalitete tehnoloških sektora CEE zemalja 
Grafikon 1. Promjena tehnoloških smjerova u CEE zemljama

\section{Vlajčić, D., Bošnjak, M.}

Utjecaj transformacije inovacijskog sustava na promjenu kvalitete tehnoloških sektora CEE zemalja

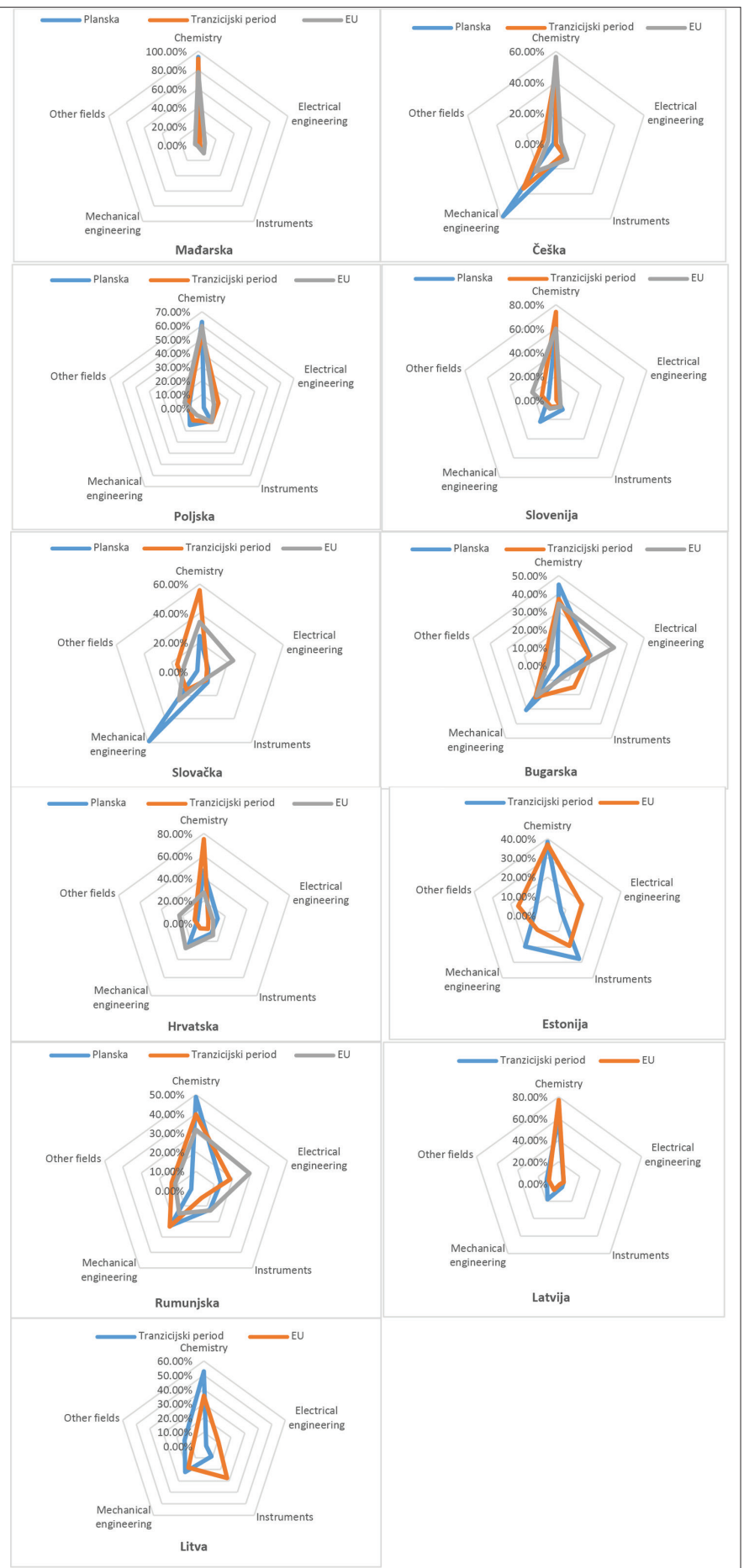

Izvor: izrada autora. 
svjetskog rata, kada su mađarska sveučilišta bila glavni promotor farmaceutske industrije (Antalóczy i suradnici, 2019.). Tranzicija s planske na tržišnu ekonomiju, ali i ulazak u EU, nije promijenio istraživačke interese u Mađarskoj. Kompanije kao što su Béres Pharmaceuticals, Egis Pharmaceuticals, Gedeon Richter, već su u planskoj ekonomiji izgradile inozemni status, a njihove istraživačke aktivnosti i danas su prepoznate diljem svijeta. Kao što se može vidjeti na Grafikonu 2.Poljska, tijekom sva tri promatrana razdoblja bilježi dominaciju kemijske industrije, pa su tako i najkvalitetnija, svjetski prepoznata tehnološka rješenja Poljske proizlaze iz iste industrije. Međutim, dominacija pojedinih polja unutar kemijske industrije zabilježila su značajne promjene.U vrijeme planske ekonomije prepoznatljivost inovativnih aktivnosti Poljske na svjetskom tržištu bilo je izgrađeno na polju organske kemije, da bi se u tranzicijskom razdoblju i razdoblju boravka u EU oslanjalo na farmaceutsku industriju. Baza za razvoj kemijske industrije u Poljskoj izgrađena je prije Prvog svjetskog rata, na naftnoj industriji (Polaczek i Zieliński, 2019.). Naime, Poljska je bila veliki dobavljač nafte za europske zemlje. Međutim, glavni generator rasta uspješnosti kemijske industrije bila je veličina tržišta koja je potaknula strane kompanije da osnuju svoje podružnice u Poljskoj (Polaczek i Zieliński, 2019.). Osamdesete godine dovele su, zbog političkih razloga, do smanjenja investicija u kemijsku industriju, što je kemijska industrija osjetila tek u devedesetima godinama. Međutim, transformacija Poljske i tranzicija u tržišno gospodarstvo dovela je ponovo do značajnih inozemnih investicija u kemijsku industriju, što se još vise intenziviralo nakon ulaska u EU (Willert, 2007.). Češka bilježi rast prehrambene industrije, međutim, vrlo brzo izdvojila se tekstilna industrija, i proizvodnja strojeva i alata. Istovremeno snažan rast zabilježila je i kemijska industrija, koja do današnjeg dana predstavlja prioritetnu industriju. Naime, snažan rast kemijske industrije može se zahvaliti činjenici kako je ona bila glavni opskrbljivač tada vodećoj prerađivačkoj industriji u zemlji, proizvodnji plastike, gume, tekstila, elektronike, papira te autoindustrije (Pavlínek i Janak, 2007.). Fokus na kemijsku industriju ostao je i nakon napuštanja planske ekonomije obzirom kako je Češka imala obrazovanu radnu snagu u polju kemije, ali bila je i centralna lokacija Europe za transport nafte. Slovačka, na osnovu velikih ulaganja, Njemačke, a poslije Sovjeta bilježi snažan rast teške industrije u vrijeme planske ekonomije (Nielsen, 2018.). Također, u isto vrijeme Slovačka je izgradila snažnu tekstilnu industriju. Tekstilna industrija zabilježila je nestanak izlaskom iz planske ekonomije, obzirom kako se nisu mogli natjecati s velikim radno intenzivnim zemljama, poput Kine (Csikósová i suradnici, 2019.). Kemijska industrija bilježi rast ulaskom sviježeg kapital u vrijeme prelaska na tržišno gospodarstvo. Naime, ona bilježi rast uslijed proizvodnje komponenti vezanih za automobilsku industriju (Brzica, 2007.). Estonija, Litva i Latvija dugo su bile dio Sovjetskog saveza, te su besplatni resursi i industrijske smjernice dolazile iz Moskve. Većina radne snage bila je angažirana u industriji proizvodnje hrane, strojarske industrije, a na temelju naftne i prehrambene industrije razvijena je i snažna kemijska industrija. Međutim, prelaskom na tržišno gospodarstvo, dostupnost besplatnih resurs nestaje, te intenzivnost radne snage u navedenim granama bilježi postepeno smanjenje.Ulaskom u EU,Estonija bilježi snažan rast u polju visoke tehnologije, što nije bio slučaj u Litvi i Latviji. Slovenija je u vrijeme planske ekonomije veliki naglasak stavljala na tešku industriju, koja je djelomično bila građena oko automobilske industrije (Slavec i Prodan, 2014.). Također, elektronička industrija bila je građena oko tvornice Gorenje (Lahovnik i Breznik, 2014.). Međutim, vjerojatno najdulju povijest Slovenije bilježi kemijska industrija. Name, navedena industrija bazirana je na dvije velike farmaceutske kompanije, Lek i Krka, osnovane odmah po završetku drugog svjetskog rata. Nakon toga, odmah je uslijedila reorganizacija edukacijskog sustava, s ciljem pojačavanja naglasaka na kemijsku industriju. Prelaskom na tržišno gospodarstvo ali i ulaskom u EU, Slovenija zadržava prioritet na farmaceutskoj industriji, prvenstveno na krilima kvalitetne radne snage $u$ navedenim sektorima. Trendovi u industriji u Hrvatskoj mijenjali su se kroz povijest. Vrijeme planskog gospodarstva obilježio je razvitak kemijske industrije. Uspjesi kemijske industrije u planskom gospodarstvu kulminirali su otkrivanjem azitromicina (PLIVA) koji postaje jedan od najprodavanijih lijekova u svijetu (Zima, 2016.).
Vlajčić, D., Bošnjak, M.

Utjecaj transformacije inovacijskog sustava na promjenu kvalitete tehnoloških sektora CEE zemalja 
Vlajčić, D., Bošnjak, M.

Utjecaj transformacije inovacijskog sustava na promjenu kvalitete tehnoloških sektora CEE zemalja
Povoljni uvjeti za razvoj dolazili su i ranim otvaranjem studija farmacije na zagrebačkom Sveučilištu, koji je generirao povoljnu radnu snagu (Ministarstvo gospodarstva, 2019.). Napuštanjem planskog gospodarstva i prelaskom na tržišno, Hrvatsku je zadesio i domovinski rat, u kojem je stradala sva industrijska proizvodnja, osim kemijske koja je bila bazirana na nekoliko velikih igrač prisutnih na svjetskom tržištu (Pliva i Ina). Geografski položaj Hrvatske također je ostavio utjecaja na industrijsku sliku. Izlaz na more rezultirao je usavršavanjem u gradnji brodova i mašinerije (Jagić, 2017.). Rumunjska bilježi dugu tradiciju automobilske industrije (Dacia,Automobile (raiova). Navedena industrija sa sobom je razvila gotovo sve segmente gospodarstva, od proizvodnje čelika do proizvodnje tekstila. Sličnu priču bilježi i naftna industrija koja bilježi početke razvoja još u 19. stoljeću, a u drugom svjetskom ratu Rumunjaka postaje najveći proizvođač nafte u Europi (Tulucan i suradnici, 2018.), a razvoj se nastavlja u vrijeme sovjetske potpore. lako zatvorena rumunjska je razvila kompjutorsku industriju, i to baziranu na kompaniji "Computer Manufacturing Company" (Filip, 1996.). Tijekom tranzicije IT industrija zabilježila je stabilan prijelaz i nastavila je rasti, prvenstveno uslijed definiranja informatičke tehnologije kao jednog od temeljnih stupova industrijske strategije. Zbog toga kroz sva tri razdoblja Rumunjska bilježi kontinuirani rast kompjutorske industrije. Bugarska je industrija, u vrijeme planske ekonomije, bila bazirana na energetskoj industriji, metalurgiji i teškoj industriji. Za razvoj svih navedenih industrija korišteni su resursi koje je Bugarska dobivala po povoljnim uvjetima od Sovjeta. Pregledom industrijskih aktivnosti CEE zemalja tijekom tri promatrana razdoblja, i usporedbom s nalazima deskriptivne statistike, može se ustanoviti podudaranje industrijskih aktivnosti zemlje $s$ inovativnim aktivnostima po kojima su te zemlje međunarodno prepoznate u navedenim razdobljima, te se tretiraju kao inovacije visoke kvalitete. Unatoč drastičnim promjenama političkog i institucionalnog okvira koje su promatrane zemlje zabilježile prolaskom kroz tri promatrana razdoblja,smjerovi industrijskog razvoja nisu zabilježili radikalne promjene. Valja napomenuti kako kvaliteta inovativnih aktivnosti CEE zemalja kroz tri razdoblja raste i to prvenstveno uslijed otvaranja ekonomija, priljeva inozemnog kapitala i rasta međunarodne suradnje.

\section{Zaključak}

Promjene političkih režima izazivaju snažne efekte na gospodarskom planu zemalja. Napuštanjem planskog i prihvaćanjem tržišnog gospodarstva, CEE zemlje zabilježile stvaranje jednog novog institucionalnog okvira, dok su ulaskom u EU prošle kroz postupak usuglašavanja institucionalnog okvira s razvijenim zapadnim članicama. CEE zemlje do početka devedesetih bile su dio Istočnog, Komunističkog bloka, ili su bile vrlo bliske po političkim i gospodarskim procesima. Osim promjena političkog i institucionalnog okvira, promatrane zemlje zabilježile su i značajno otvaranje i restrukturiranje inovacijskog sustava, nekoć zaključanog u suradnju s pretežito lokalnom okolinom, odnosno zemljama iz bloka. Priljevom stranog kapitala, ali i tehnologije i znanja, CEE zemlje bilježe pomake u kvalitete, a time i prihvaćenosti njihovih inovacija na globalnom tržištu je poraslo. Tehnološki ciklusi kontinuirano mijenjaju tehnološke putanje, a brza adaptacija na suvremene inovacijske trendove ključ za održavanje konkurentne pozicije. U navedenom procesu značajnu ulogu igra brzina prihvaćanja novih trendova, ali i heterogenost tehnološkog portfelja. Poznato je kako diversifikacija tehnološkog portfelja omogućava generiranje radikalnih, ali i kvalitetnijih inovacija. Zemlje CEE regije znatno su manje konkurentne jer su tehnološki specijalizirane, čime su i znatno manje otporne na smjene globalnih tehnoloških trendova.Udio međunarodno prepoznatih patenata u ukupnim patentima, i dalje je niska, međutim udio se značajno povećao ulaskom u Europsku uniju. Očekuje se kako će se navedeni trend nastaviti obzirom na rast stabilnosti zemalja i povećanog priljeva inozemnog kapitala. Ovim radom pokazuje se kako je vrijeme provedeno u planskoj ekonomiji rezultiralo gradnjom specifičnih proizvodnih kapaciteta, te prelaskom na tržišno gospodarstvo navedene zemlje nisu se uspjele značajno osloboditi tehnološkog nasljeđa (eng. technology lock-in effect). Nadalje, povijesno nasljeđe toliko je duboko utkano u njihove proizvodne mogućnosti da niti ulazak u Europsku uniju, zasada, nije donio značajnije pomake u smjerovima inovativnih aktivnosti. Obzirom na sve 
veći naglasak na „Pametnu specijalizaciju“ unutar strategija Europske unije za razvoj konkurentnosti zemalja članica, nije za očekivati značajnije pomake u razvoju tehnoloških smjerova, odnosno značajniju diversifikaciju tehnološkog portfelja. Izgledno je kako će regionalna znanja i mogućnosti biti baza i za daljnje tehnološke razvoje promatranih zemalja. Nedvojbeno je kako za donošenje pravih i kvalitetnih razvojnih politika nužno poznavanje obrazaca kretanja tehnologija.Naime, razumijevanje nastanka novih, ali i nestanka starih, tehnoloških područja moglo bi pomoći u usmjeravanju javne politike, izravnim ulaganjima i smanjenju rizika. Jedno od najvećih ograničenja ovog rada proizlazi iz činjenice kako je u vrijeme planske ekonomije bila izražena politička i ekonomska isprepletenost grupa CEE zemalja. Navedeno bi moglo ukazati kako je međunarodna prepoznatost inovacija rezultat političkog angažmana. To se prvenstveno odnosi na Sloveniju, Češku, Slovačku, Hrvatsku, Latviju, Litvu i Estoniju.

\section{Literatura}

Adner, R., \& Snow, D. (2010). Old technology responses to new technology threats: demand heterogeneity and technology retreats. Industrial and Corporate Change, 19(5), 1655-1675. https://doi.org/10.1093/icc/dtq046

Antalóczy, K., Gáspár, T., \& Sass, M. (2019). The specialties of the pharmaceutical value chains in Hungary. Acta Oeconomica, 69(S2), 41-72. https://doi.org/10.1556/032.2019.69.S2.3

Balázs, K. (1993). Lessons from an economy with limited market functions: R\&D in Hungary in the 1980s. Research Policy, 22(5-6), 537-552. https://doi.org/10.1016/0048-7333(93)90017-C

Börzel, T. A., \& Sedelmeier, U. (2017). Larger and more law abiding? The impact of enlargement on compliance in the European Union. Journal of European Public Policy, 24(2), 197-215. https://doi.org/10.1080/13501763.2016.1265575

Boschma, R., Balland, P.A., \& Kogler, D. F. (2015). Relatedness and technological change in cities: the rise and fall of technological knowledge in US metropolitan areas from 1981 to 2010. Industrial and corporate change, 24(1), 223-250. https://doi.org/10.1093/icc/dtu012

Boutellier, R., Gassmann, 0., \& Von Zedtwitz, M. (2013). Managing global innovation: uncovering the secrets of future competitiveness. Springer Science \& Business Media.

Bradshaw, M. J. (2017). Foreign direct investment and economic transformation in Central and Eastern Europe. In: Foreign Direct Investment and Regional Development in East Central Europe and the Former Soviet Union, Turnock, D. (ur.). Routledge: 3-19.

Brzica, D. (2007). Automobile Sector in the Slovak Republic: Current Situation and Future Prospects. In Regional Externalities, Hejiman, W. (ur.). Springer, Berlin, Heidelberg: 131-147.

Carmin, J., \& VanDeveer, S. D. (2004). Enlarging EU environments: Central and Eastern Europe from transition to accession. Environmental Politics, 13(1), 3-24. https://doi.org/10.1080/09644010410001685119

Chen, Y.M., Yang, D.-H., \& Lin, F.J. (2013). Does technological diversification matter to firm performance? The moderating role of organizational slack. Journal of Business Research, 66, 1970-1975. https://doi.org/10.1016/j.jbusres.2013.02.020

Csikósová, A., Janošková, M., \& Čulková, K. (2019). Prediction of developments in the textile and clothing industry in Slovakia by selected indicators of financial analysis. Fibres \& textiles in Eastern Europe, 4(136), 
Vlajčić, D., Bošnjak, M.

Utjecaj transformacije inovacijskog sustava na promjenı kvalitete tehnoloških sektora CEE zemalja

\section{9-16.https://doi.org/10.5604/01.3001.0013.1814}

Dominguez Lacasa, I., \& Giebler,A. (2014). Technological activities in CEE countries: A patent analysis for the period 1980-2009 (No. 2/2014). IWH Discussion Papers.

Dosi, G. (1982). Technological paradigms and technological trajectories: a suggested interpretation of the determinants and directions of technical change. Research policy, 11(3), 147-162. https://doi.org/10.1016/0048-7333(82)90016-6

Ejermo, 0. (2009). Regional Innovation Measured by Patent Data-Does Quality Matter? Research Paper. Industry and Innovation, 16(2), 141-165. https://doi.org/10.1080/13662710902764246

EPO (2021). Espacenet. Dostupno na: http://www.epo.org/searching/free/espacenet.html (20.08.2021.).

European Commission (2020). Strategic plan 2020-2024 - Research and Innovation. Dostupno na: https://ec.europa.eu/info/sites/default/files/rtd_sp_2020_2024_en.pdf,(10.09.2021.).

EXPRESS (2010). Standardization for a competitive and innovative Europe: a vision for 2020. Dostupno na: http://www.anec.eu/attachments/Definitive\%20EXPRESS\%20report.pdf (10.07.2021.).

Filip, F. G. (1996). Information technology culture dissemination in Romania. Knowledge, Technology Transfer and Foresight, 149-159.

Fleming, L. (2001). Recombinant uncertainty in technological search. Management science, 47(1), 117132. https://doi.org/10.1287/mnsc.47.1.117.10671

Giuri, P., Mariani, M., Brusoni, S., Crespi, G., Francoz, D., Gambardella, A., \& Verspagen, B. (2007). Inventors and invention processes in Europe: Results from the PatVal-EU survey. Research policy, 36(8), 1107-1127. https://doi.org/10.1016/j.respol.2007.07.008

Guellec, D., \& de la Potterie, B. V. P. (2000). Applications, grants and the value of patent. Economics letters, 69(1), 109-114. https://doi.org/10.1016/50165-1765(00)00265-2

Guellec, D., \& Van Pottelsberghe de la Potterie, B. (2002). The value of patents and patenting strategies: countries and technology areas patterns. Economics of Innovation and New Technology, 11(2), 133-148. https://doi.org/10.1080/10438590210896

Guillén, M. F. (2000). Business groups in emerging economies: A resource-based view. Academy of Management Journal, 43(3),362-380. https://doi.org/10.2307/1556400

Hacklin, F., Björkdahl,J., \& Wallin, M.W.(2018). Strategies for business model innovation: How firms reel in migrating value. Long range planning, 51(1), 82-110. https://doi.org/10.1016/j.lrp.2017.06.009

Hall,B. H.,Jaffe,A., \& Trajtenberg, M.(2005).Market value and patent citations. RAND Journal of economics, 16-38.

Hare, P. G. (1991). Hungary: In transition to a market economy. Journal of Economic Perspectives, 5(4), 195-201. https://doi.org/10.1257/jep.5.4.195

Harhoff, D., Scherer, F. M., \& Vopel, K. (2003). Citations, family size, opposition and the value of patent rights. Research policy, 32(8),1343-1363. https://doi.org/10.1016/50048-7333(02)00124-5

Jagić, I. (2017). Natural and cultural heritage interpretation for the sustainable development of local communities. Models of valorisation of cultural heritage in sustainable tourism, 228.

Karo, E., \& Kattel, R. (2015). Economic development and evolving state capacities in Central and Eastern Europe: can "smart specialization" make a difference?. Journal of Economic Policy Reform, 18(2), 172-187. https://doi.org/10.1080/17487870.2015.1009068

Kirankabeş, M. C., \& Erkul, A. (2019). Regional knowledge production in Central and East European countries: R\&D factor productivity and changes in performances. Eastern Journal of European Studies, 10(1), $25-44$. 
Klepper, S. (1996). Entry, exit, growth, and innovation over the product life cycle. The American economic review, 86(3), 562-583. https://doi.org/10.1023/A:1025067906102

Kodama, M. (2009). Boundary management: developing business architectures for innovation. Springer Science \& Business Media.

Kozlowski, J., Radosevic, S., \& Ircha, D. (1999). History matters: The inherited disciplinary structure of the post-communist science in countries of central and Eastern Europe and its restructuring. Scientometrics, 45(1), 137-166. https://doi.org/10.1007/BF02458473

Kutlaca, D. G. (1999). Innovation Activities in Open and Closed Economic Environments: The Case of the Yugoslav Metal-Processing, Chemicals and Textile Industries in 1987-91 and 1992-96. In Innovation and Structural Change in Post-Socialist Countries: A Quantitative Approach, Dyker, D. \& Radosevic, S. (ur.). Springer, Dordrecht: 307-329.

Lacasa, I. D., Giebler, A., \& Radosevic, S. (2017). Technological capabilities in Central and Eastern Europe: an analysis based on priority patents. Scientometrics, 111(1), 83-102. https://doi.org/10.1007/s11192-017-2277-2

Lahovnik, M., \& Breznik, L. (2014). Technological innovation capabilities as a source of competitive advantage: A case study from the home appliance industry. Transformations in business \& economics, 13(2), 144-160.

Lanjouw, J. 0., \& Schankerman, M. (2004). Patent quality and research productivity: Measuring innovation with multiple indicators. The Economic Journal, 114(495), 441-465. https://doi.org/10.1111/j.1468-0297.2004.00216.x

McMillan,J., \& Naughton, B. (1992). How to reform a planned economy: lessons from China. Oxford review of economic policy, 8(1), 130-143. https://doi.org/10.1093/oxrep/8.1.130

Ministarstvo gospodarstva (2019). Pharmaceutical Industry. Dostupno na: http://investcroatia.gov.hr/en/ sectors/pharmaceutical-industry/ (10.09.2021.).

Moodysson, J., \& Jonsson, 0. (2007). Knowledge collaboration and proximity: The spatial organization of biotech innovation projects. European urban and regional studies, 14(2), 115-131. https://doi.org/10.1177/0969776407075556

Murmann, J. P., \& Frenken, K. (2006). Toward a systematic framework for research on dominant designs, technological innovations, and industrial change. Research policy, 35(7), 925-952. https://doi.org/10.1016/j.respol.2006.04.011

WIPO (2021). The Nice Classification (NCL). Dostupno na: https://www.wipo.int/classifications/nice/en/ (01.09.2021.).

Nielsen, H. (2018). Technology and scale changes: the steel industry of a planned economy in a comparative perspective. Economic History of Developing Regions, 33(2), 90-122. https://doi.org/10.1080/20780389.2018.1432353

Organisation for Economic Co-Operation, \& Development Staff (2001). Agricultural Policies in OECD Countries-Monitoring and Evaluation 2001. Organization for Economic.

Pavlínek, P., \& Janák, L. (2007). Regional restructuring of the Škoda auto supplier network in the Czech Republic.European urban and regional studies,14(2),133-155.https://doi.org/10.1177/0969776407076101

Pelkmans, J., \& Renda, A. (2014). How can EU legislation Enable and/or Disable Innovation. European Commission. Dostupno na: https://ec. europa.eu/futurium/en/system/files/ged/39-how_can_eu_legislation_ enable_andor_disable_innovation. pdf.(10.08.2021.).

Picci, L. (2010).The internationalization of inventive activity: A gravity model using patent data. Research Policy, 39(8), 1070-1081.https://doi.org/10.1016/j.respol.2010.05.007 
Vlajčić, D., Bošnjak, M.

Utjecaj transformacije inovacijskog sustava na promjenu kvalitete tehnoloških sektora CEE zemalja
Polaczek, J., \& Zieliński, T. (2019). Development of chemical industry in Poland. Achievements and constraints. Polish Technical Review.

Quintana-García, C., \& Benavides-Velasco, C. A. (2011). Knowledge organization in R\&D alliances: its impact on product innovation. Technology Analysis and Strategic Management, 23(10), 1047-1061. https://doi.org/10.1080/09537325.2011.621300

Radosevic, S. (1999). Transformation of science and technology systems into systems of innovation in central and eastern Europe: the emerging patterns and determinants. Structural Change and Economic Dynamics, 10(3-4), 277-320. https://doi.org/10.1016/50954-349X(99)00016-8

Radosevic, S., \& Auriol, L. (1999). Patterns of restructuring in research, development and innovation activities in central and eastern European countries: an analysis based on S\&T indicators. Research Policy, 28(4), 351-376.

Schumpeter, J. (1934). Depressions. In Economics of the Recovery Program, Brown, D. et al. (ur.). New York: McGraw-Hill.

Sichelman, T.M.(2011). Taking Commercialisation Seriously. European Intellectual Property Review, 33(4), 11-050.

Slavec, A., \& Prodan, I. (2014). The Slovenian Automotive Cluster. Cluster Development in the Czech Republic and Slovenia, Faculty of Economics, Ljubljana.

Squicciarini, M., Dernis, H., \& Criscuolo, C. (2013). Measuring patent quality: Indicators of technological and economic value.OECD. Dostupno na: https://www.oecd-ilibrary.org/science-and-technology/measuringpatent-quality_5k4522wkw1r8-en (01.09.2021.).

Tulucan, A. D., Soveja-lacob, L. E., \& Krezsek, C. (2018). History of the oil and gas industry in Romania. Geological Society, London, Special Publications, 465(1), 191-200. https://doi.org/10.1144/SP465.15

Willert, P. L. (2007). Assessment of the pharmaceutical market in Poland after accession to the European Union. The European Journal of Health Economics, 8(4), 347-357. https://doi.org/10.1007/s10198-006-0032-3

Zima, M. (2016). Pogled na povijesno otkriće Plivina azitromicina. Doktorska disertacija, University of Zagreb. Faculty of Pharmacy and Biochemistry. 
Tablica 2. Tehnološka polja patenata prema udjelu u ukupnom broju inozemno registriranih patenata CEE zemalja

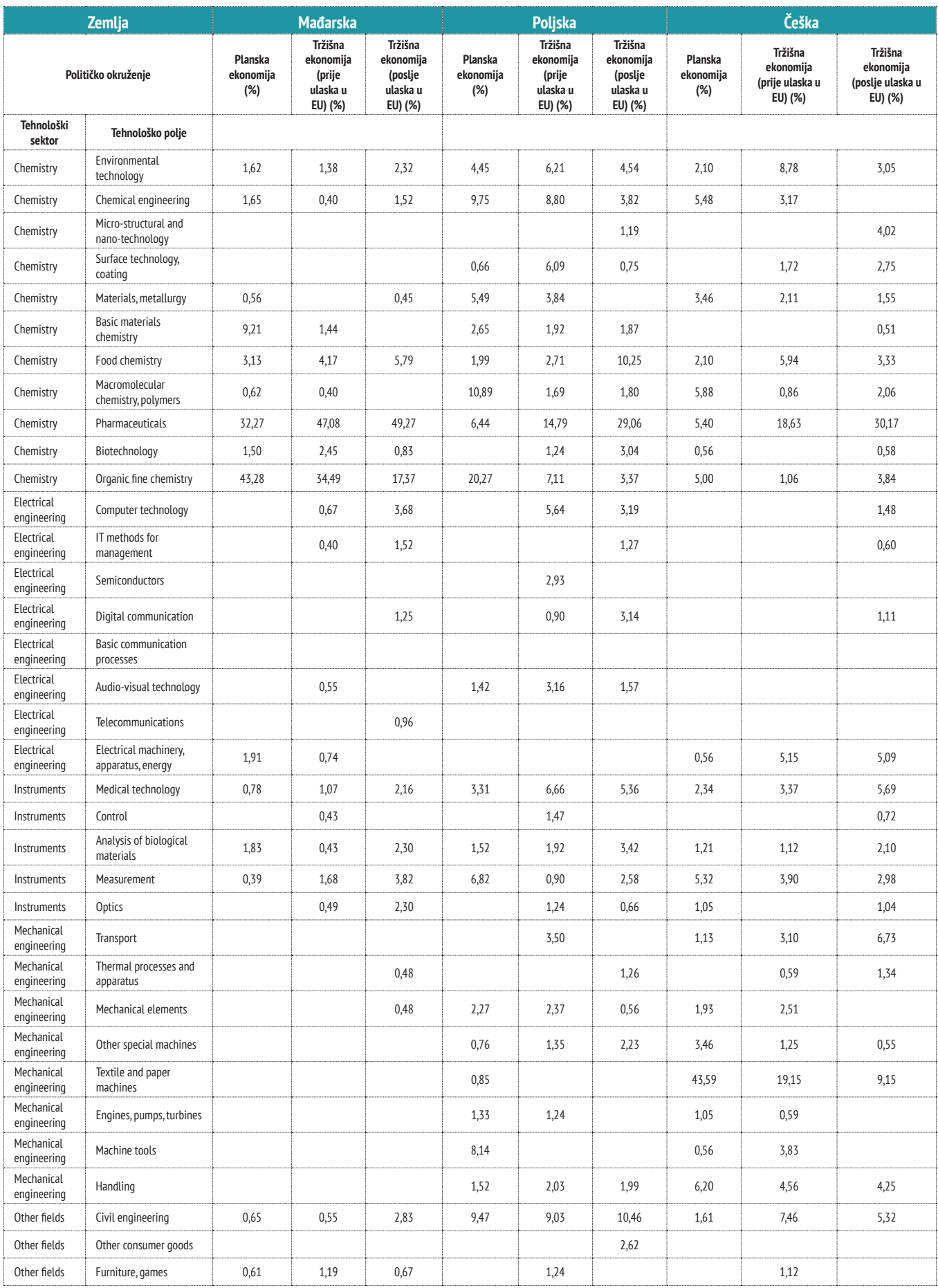




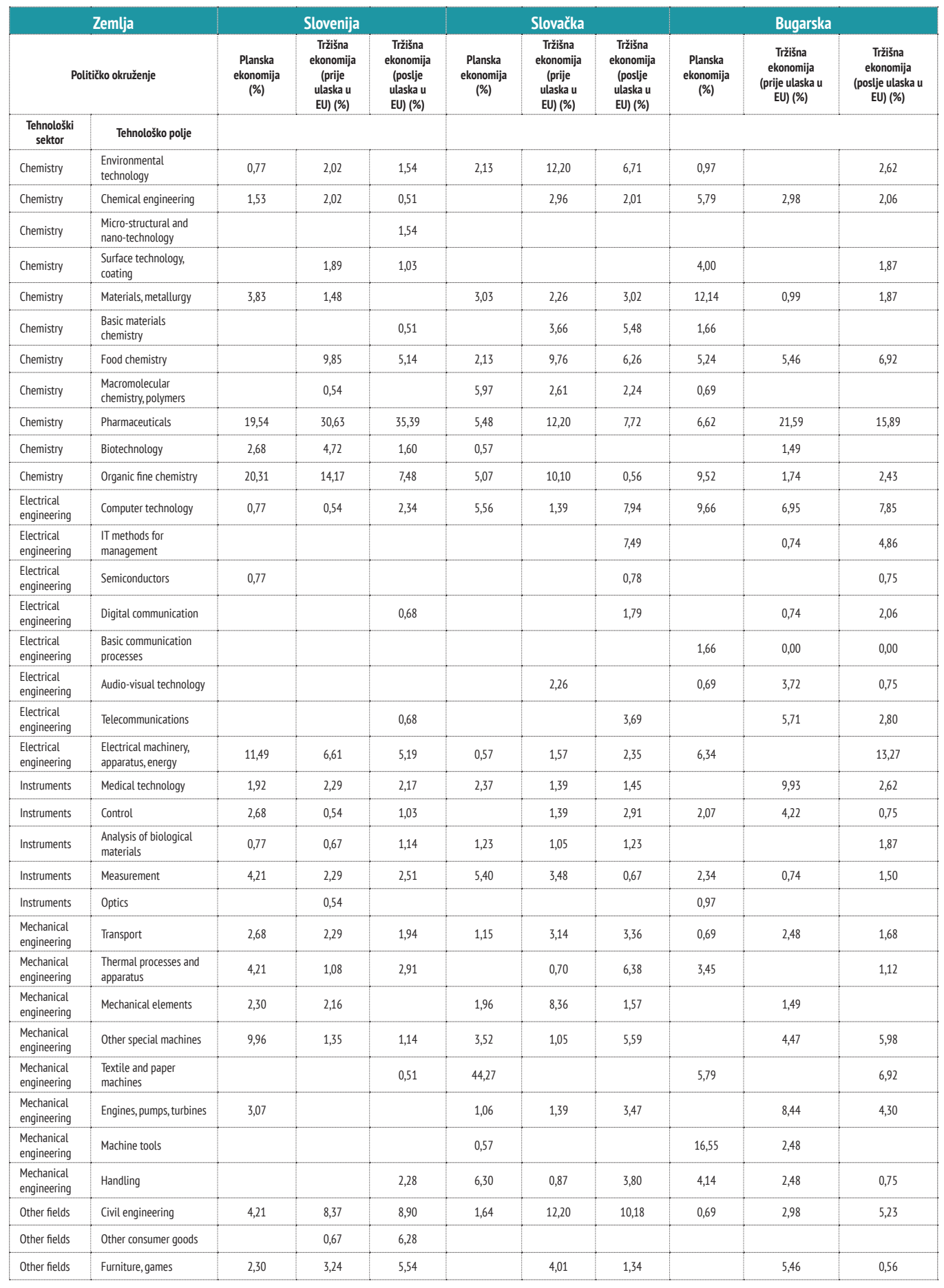




\begin{tabular}{|c|c|c|c|c|c|c|c|c|c|}
\hline \multicolumn{2}{|c|}{ Zemlja } & \multicolumn{3}{|c|}{ Rumunjska } & \multicolumn{3}{|c|}{ Hrvatska } & \multicolumn{2}{|c|}{ Estonija } \\
\hline \multicolumn{2}{|c|}{ Političko okruženje } & $\begin{array}{c}\text { Planska } \\
\text { ekonomija } \\
(\%)\end{array}$ & $\begin{array}{c}\text { Tržišna } \\
\text { ekonomija } \\
\text { (prije } \\
\text { ulaska u } \\
\text { EU) (\%) }\end{array}$ & $\begin{array}{c}\text { Tržišna } \\
\text { ekonomija } \\
\text { (poslje } \\
\text { ulaska u } \\
\text { EU) (\%) }\end{array}$ & $\begin{array}{c}\text { Planska } \\
\text { ekonomija } \\
(\%)\end{array}$ & $\begin{array}{c}\text { Tržišna } \\
\text { ekonomija } \\
\text { (prije } \\
\text { ulaska u } \\
\text { EU) (\%) }\end{array}$ & $\begin{array}{l}\text { Tržišna } \\
\text { ekonomija } \\
\text { (poslje } \\
\text { ulaska u } \\
\text { EU) (\%) }\end{array}$ & $\begin{array}{c}\text { Tržišna } \\
\text { ekonomija } \\
\text { (prije } \\
\text { ulaska u } \\
\text { EU) (\%) }\end{array}$ & $\begin{array}{c}\text { Tržišna } \\
\text { ekonomija } \\
\text { (poslje ulaska u } \\
\text { EU) (\%) }\end{array}$ \\
\hline $\begin{array}{l}\text { Tehnološki } \\
\text { sektor }\end{array}$ & Tehnološko polje & & & & & & & & \\
\hline Chemistry & $\begin{array}{l}\text { Environmental } \\
\text { technology }\end{array}$ & 3,56 & 4,20 & 2,63 & & 1,32 & 3,41 & 0,62 & 1,92 \\
\hline Chemistry & Chemical engineering & 8,90 & 2,29 & 2,96 & 4,51 & & 1,52 & 6,17 & 1,73 \\
\hline Chemistry & $\begin{array}{l}\text { Micro-structural and } \\
\text { nano-technology }\end{array}$ & & & & & & & & 0,58 \\
\hline Chemistry & $\begin{array}{l}\text { Surface technology, } \\
\text { coating }\end{array}$ & & 0,76 & 1,48 & & & & 1,85 & 3,65 \\
\hline Chemistry & Materials, metallurgy & 4,27 & 5,34 & & 0,75 & & & & 1,15 \\
\hline Chemistry & $\begin{array}{l}\text { Basic materials } \\
\text { chemistry }\end{array}$ & 7,12 & 3,82 & 11,84 & & & 2,65 & 1,85 & 3,65 \\
\hline Chemistry & Food chemistry & 1,42 & & 3,45 & & 0,41 & 3,03 & 15,43 & 14,62 \\
\hline Chemistry & $\begin{array}{l}\text { Macromolecular } \\
\text { chemistry, polymers }\end{array}$ & 3,20 & 1,53 & 0,82 & & & & & \\
\hline Chemistry & Pharmaceuticals & 13,17 & 19,85 & 8,55 & 19,17 & 52,36 & 15,15 & 8,02 & 8,46 \\
\hline Chemistry & Biotechnology & & & & 2,63 & & & 3,09 & 1,15 \\
\hline Chemistry & Organic fine chemistry & 7,12 & 1,91 & & 19,92 & 20,84 & 1,52 & 1,23 & \\
\hline $\begin{array}{l}\text { Electrical } \\
\text { engineering }\end{array}$ & Computer technology & & 1,53 & 17,11 & 0,75 & 1,65 & 3,03 & 4,32 & 4,81 \\
\hline $\begin{array}{l}\text { Electrical } \\
\text { engineering }\end{array}$ & $\begin{array}{l}\text { IT methods for } \\
\text { management }\end{array}$ & & & 1,64 & & 0,41 & & 1,23 & 5,77 \\
\hline $\begin{array}{l}\text { Electrical } \\
\text { engineering }\end{array}$ & Semiconductors & & & & 0,75 & & & & \\
\hline $\begin{array}{l}\text { Electrical } \\
\text { engineering }\end{array}$ & Digital communication & & 1,91 & 8,06 & & 0,91 & & 1,85 & 2,69 \\
\hline $\begin{array}{l}\text { Electrical } \\
\text { engineering }\end{array}$ & $\begin{array}{l}\text { Basic communication } \\
\text { processes }\end{array}$ & & & & & & & & 0,77 \\
\hline $\begin{array}{l}\text { Electrical } \\
\text { engineering }\end{array}$ & Audio-visual technology & & 1,15 & & & 0,50 & & & \\
\hline $\begin{array}{l}\text { Electrical } \\
\text { engineering }\end{array}$ & Telecommunications & & 1,15 & & & 0,58 & 1,14 & & 0,77 \\
\hline $\begin{array}{l}\text { Electrical } \\
\text { engineering }\end{array}$ & $\begin{array}{l}\text { Electrical machinery, } \\
\text { apparatus, energy }\end{array}$ & 13,52 & 12,98 & 2,47 & 11,28 & & 4,17 & & 3,85 \\
\hline Instruments & Medical technology & 5,69 & 0,76 & 8,88 & 1,88 & 4,63 & 4,17 & 21,60 & 6,73 \\
\hline Instruments & Control & & & 0,66 & 2,63 & 0,50 & 1,89 & 1,85 & 2,50 \\
\hline Instruments & $\begin{array}{l}\text { Analysis of biological } \\
\text { materials }\end{array}$ & & & 1,15 & 0,75 & 0,58 & 1,89 & 1,85 & 4,04 \\
\hline Instruments & Measurement & 6,76 & 1,53 & 2,14 & 6,02 & 0,58 & 5,68 & 2,47 & 4,23 \\
\hline Instruments & Optics & & 2,67 & & & & & & 1,92 \\
\hline $\begin{array}{l}\text { Mechanical } \\
\text { engineering }\end{array}$ & Transport & 4,27 & 3,05 & 2,30 & 2,63 & 2,15 & 3,79 & 0,62 & \\
\hline $\begin{array}{l}\text { Mechanical } \\
\text { engineering }\end{array}$ & $\begin{array}{l}\text { Thermal processes and } \\
\text { apparatus }\end{array}$ & 1,42 & 6,11 & 1,48 & 4,14 & & 1,52 & & 3,08 \\
\hline $\begin{array}{l}\text { Mechanical } \\
\text { engineering }\end{array}$ & Mechanical elements & & 2,29 & 1,32 & 2,26 & & 5,68 & & \\
\hline $\begin{array}{l}\text { Mechanical } \\
\text { engineering }\end{array}$ & Other special machines & & & 0,66 & 9,77 & 0,50 & 1,52 & 9,26 & 1,54 \\
\hline $\begin{array}{l}\text { Mechanical } \\
\text { engineering }\end{array}$ & $\begin{array}{l}\text { Textile and paper } \\
\text { machines }\end{array}$ & 2,85 & & & & & 4,92 & 6,79 & \\
\hline $\begin{array}{l}\text { Mechanical } \\
\text { engineering }\end{array}$ & Engines, pumps, turbines & 7,12 & 8,78 & 8,39 & 3,76 & 2,89 & 6,44 & 1,23 & 1,15 \\
\hline $\begin{array}{l}\text { Mechanical } \\
\text { engineering }\end{array}$ & Machine tools & 3,91 & 3,05 & & & & 1,52 & 0,62 & 1,15 \\
\hline $\begin{array}{l}\text { Mechanical } \\
\text { engineering }\end{array}$ & Handling & 3,20 & & 0,66 & & 0,41 & 2,27 & 1,23 & 2,12 \\
\hline Other fields & Civil engineering & 1,42 & 7,63 & 8,22 & 4,14 & 6,87 & 10,61 & 1,23 & 11,54 \\
\hline Other fields & Other consumer goods & 1,07 & 1,53 & 2,14 & & 0,66 & 7,95 & 1,85 & 0,58 \\
\hline Other fields & Furniture, games & & 4,20 & 0,99 & 2,26 & 1,24 & 4,55 & 3,70 & 3,85 \\
\hline
\end{tabular}




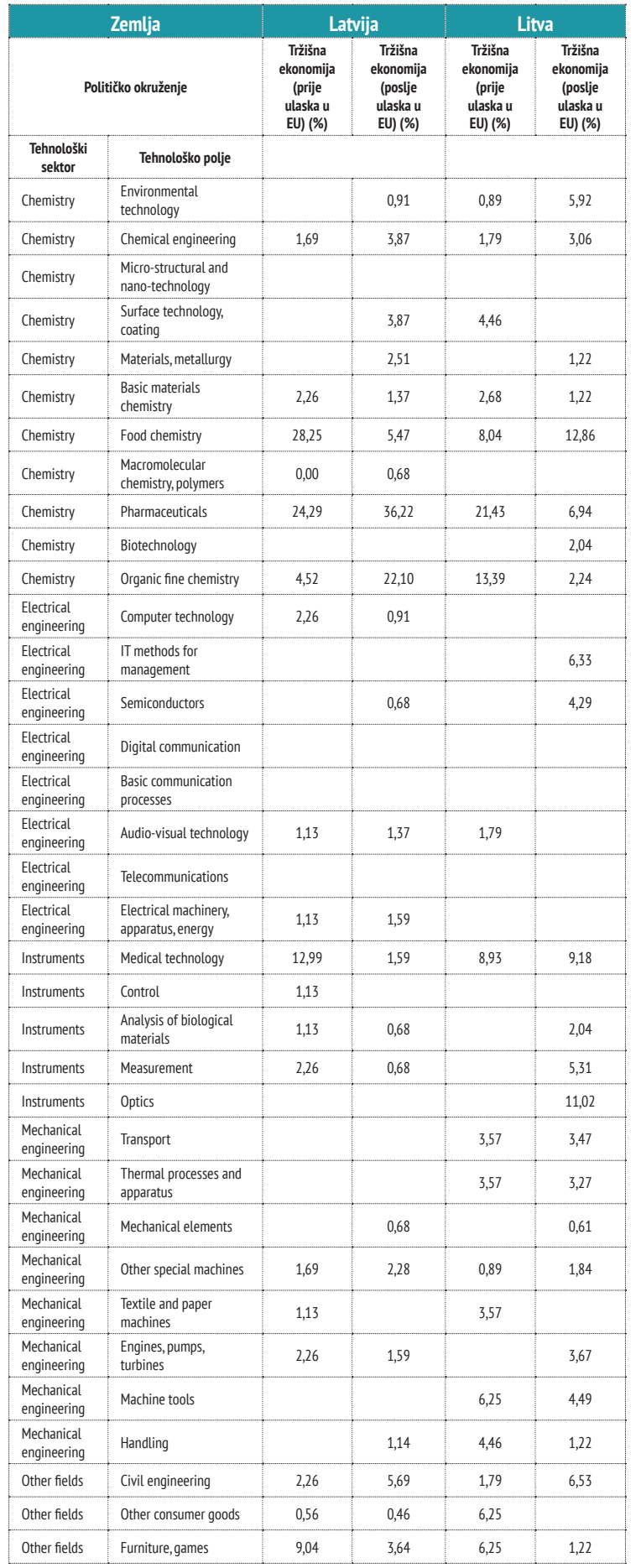

Grafikon 2. Udio inozemno registriranih patenata u ukupnom broju patenata prema godinama
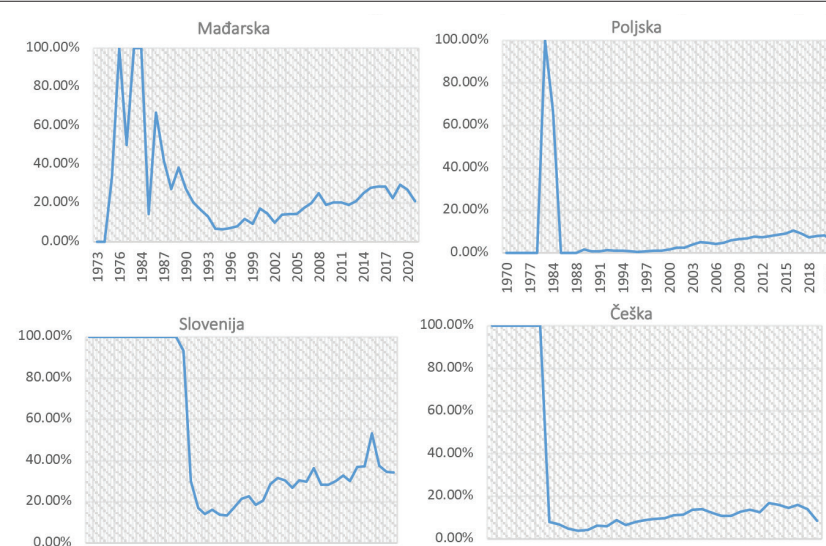

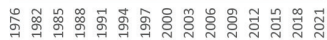

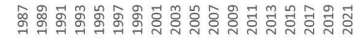

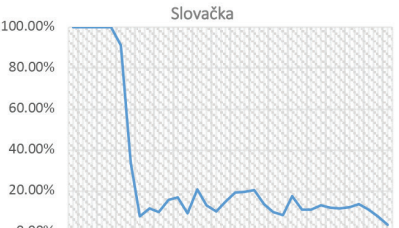

$0.00 \%$
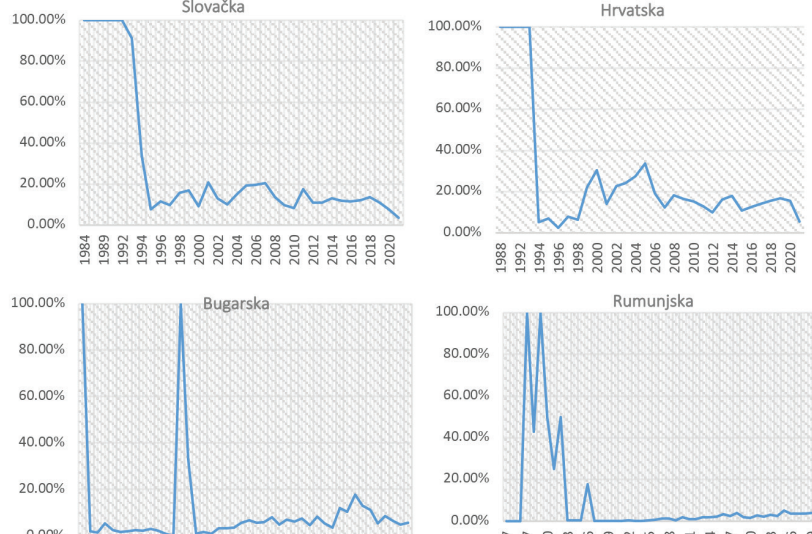

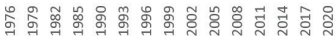

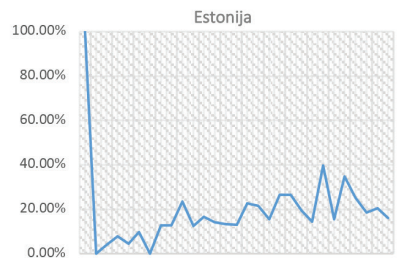

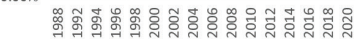

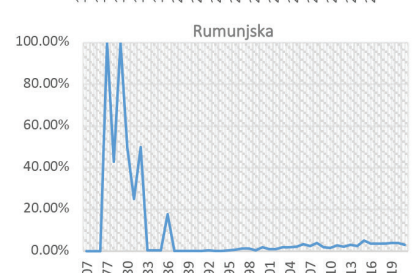

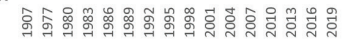
Latvia
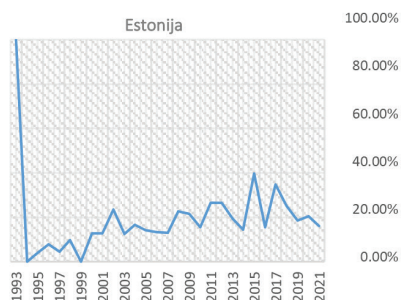
Litva

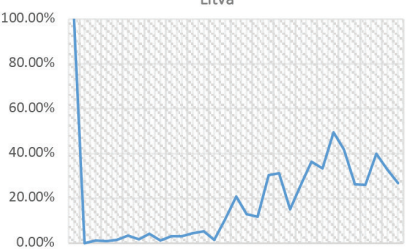

